\title{
The Effects of Problem-Based Learning on Self-Regulated Learning Skills and the Variables Predictive of These Skills
}

\author{
Senar Temel \\ Department of Chemistry Education \\ University of Hacettepe, Ankara, Turkey \\ senar@hacettepe.edu.tr
}

Doi:10.5901/mjss.2013.v4n14p297

\begin{abstract}
This study aimed to compare the effects of problem-based learning with traditional teaching method on prospective teachers' self-regulated learning skills. In addition to that, the study also set out to determine the levels of attitudes towards problembased learning and self-efficacy perceptions of problem-based learning of prospective teachers and to check whether or not the two variables are significant predictors of self-regulated learning skills. 49 prospective teachers from the Department of Secondary Science and Mathematics Education, Faculty of Education, Hacettepe University, participated in this study. The study data were collected with The Self-Regulated Learning Scale, The Attitude Scale Towards Problem-Based Learning, and The Scale of Self-Efficacy Perception of Problem-Based Learning. In the light of the findings, it was found that the problembased learning and the traditional teaching method did not have significant effects on prospective teachers' self-regulated learning skills. It was also found that the prospective teachers' attitudes towards and their self-efficacy perceptions of problembased learning were at the middle level, and that the two variables accounted for $49 \%$ of the total variance in self-regulated learning skills.
\end{abstract}

Keywords: attitude, self-efficacy perception, self-regulated learning skill, problem-based learning, traditional teaching method

\section{Introduction}

In parallel to the developments in science, it was regarded that knowledge reached by reason and observation was not absolute and always valid; and this conception caused moving away from the mentality of education directed to loading knowledge. Hence, the roles undertaken by teachers and learners in the process of education have changed, and consequently, learners' taking the responsibility of and being effective in their own learning caused the concept of selfregulation to emerge (Üredi \& Üredi, 2007). The concept of self-regulation was first suggested by Bandura, the founder of social cognitive learning theory (Senemoğlu, 2011), and was then defined by several other researchers. According to Rizemberg and Zimmerman (1992), self-regulation is setting goals, developing strategies in order to attain those goals, and controlling what gains the strategies lead to. Perry and Drummond (2002) contend that it is students' awareness of the factors influential in their motivation to learn and to take responsibility.

Self-regulated learning, which developed in consequence of students' controlling the process of learning and with their awareness of the processes, is among the objectives of problem-based learning (PBL) (Taşkın, 2008). "PBL provides opportunities for self-regulated learning by offering students choices and control about what to work on, how to work, and what products to generate" (Paris \& Paris, 2001, p. 94). "It makes students responsible for finding information, coordinating actions and people, reaching goals, and monitoring understanding" (Paris \& Paris, 2001, p. 94). Students take part in cooperative groups and try to determine what they need to learn in order to solve the problems in the PBL. They engage in self-directed learning and at the same time they use the knowledge obtained in the solution of the problems, and reflect what they have learnt and the effectiveness of the strategies they have used. Therefore, PBL is a method helping students to be active in solving the real-world problems and ensuring that they take the responsibility of their learning (Lee, Shen \& Tsai, 2010). Study results of Sungur and Tekkaya (2006) revealed that PBL enhances the self-regulatory skills of 10th-grade students. Ertmer, Newby and MacDougall (1996) conducted a qualitative study of how veterinary students approached learning from problems. Low self-regulated learning students had difficulty adapting to the kind of learning required in problem-based instruction. High self-regulated learning students valued learning from problems and tended to focus on the problem analysis and reflection process.

Self-regulatory processes are teachable (Schunk \& Zimmerman, 1998) and self-regulated learning depends on 
motivation and control (Corno, 1993; as cited in Paris \& Paris, 2001), but "self-regulated learning skills are of little value if students do not motivate themselves to use them" (Sungur \& Tekkaya, 2006, p. 307). According to Pintrich (1999):

The use of various cognitive and self-regulatory strategies involves a level of engagement that is often more demanding in terms of time and effort for students than their normal level of engagement. In order for them to invest the extra time and effort in self-regulated learning, they must be motivated to use these various strategies. (p. 467).

Hence, one of the motivational beliefs developing and sustaining self-regulated learning is self-efficacy (Pintrich, 1999). Self-efficacy is individuals' judgements of how well they can perform the actions necessary for coping with probable situations (Bandura, 1982) and their belief in their capacities of doing the activities needed for achieving a certain amount of performance (Bandura, 1986). Self-efficacy is extremely important for self-regulated learning because it affects the extent to which learners engage and persist at challenging tasks. Students with higher self-efficacy are more likely to engage in a difficult task and more likely to persist at a task even in the face of initial failures compared to lowefficacy students (Pajares, 1996). Findings of several studies (Pintrich, 1989; Pintrich \& De Groot, 1990; Pintrich \& Garcia, 1991; Pintrich, 1999) conducted with middle school and college students showed very positive relations between self-efficacy and self-regulated learning. İsrael (2007), on the other hand, found a moderate level positive correlation between self-regulation and self-efficacy in science.

Being able to regulate your own learning is viewed by educational psychologists alike as the key to successful learning in school and beyond. Researchers have designed powerful new learning environments in which the knowledge, skills, and attitudes associated with self-regulation can be acquired (Boekaerts, 1999, p. 446).

Since the PBL and similar approaches included in those new leaning environments require the develeopment of self-regulated leaning skills, the inclusion of the approaches supporting the development of those skills in the earlier period in the curriculum can help students in facilitating those skills and in the development of affective properties (Turan \& Demirel, 2011). The fact that students' affective characteristics during application of the curriculum were determined is one of the issues that curriculum developers focus on; because there may be attitudes to instill in students through the implementation of the curriculum and it is also possible that the attitudes gained before and during the curriculum can hinder or make difficult the things to be learnt. In this context, it is important that students' attitudes should be determined in conducting the PBL (Turan \& Demirel, 2009). Attitude is a tendency attributed to an individual, and is not an observable behaviour (Kağıtçıbaşı, 1996). An attitude is acquired through experience. The attitude gained can be shaped in time through various effects and by giving positive messages (Gömleksiz, 2003). According to Tosun and Senocak (2013):

Student attitudes are considerably related to motivation and success. Having high skills and talents is not enough for students to complete a task successfully and to make them like an activity as they are doing it. In order to sustain students' motivation, a positive opinion about the learning task and an internal stimulus is needed. Attitudes and beliefs are accepted as the pioneers of behavioral objectives. The probability of having willingness about learning tasks and sustainability of efforts is higher in students with a positive attitude. (p. 63).

A review of literature in the light of the above mentioned issues makes it clear that the PBL is considered important in the development of self-regulated learning. Yet, the need for research into the effects of PBL on the development of self-regulated learning especially in science education is one of the reasons for performing this study. Additionally, the fact that research concerning the relations between self-efficacy and self-regulated learning is often at high school and college levels, and that the researches related to the attitudes towards PBL mainly come from medical literature (Birgegard \& Lindquist, 1998; Kaufman \& Mann, 1996; Vernon, 1995 ) are among the other reasons for performing this current research.

\subsection{The purpose of the study}

This study aimed to compare the effects of problem-based learning with traditional teaching method on prospective teachers' self-regulated learning skills. In addition to that, the study also set out to determine the levels of attitudes towards problem-based learning and self-efficacy perceptions of problem-based learning of prospective teachers and to check whether or not the two variables are significant predictors of self-regulated learning skills. In line with these purposes, answers were sought to the following research questions:

- Is there a statistically significant difference between prospective teachers' self-regulated learning skills according to the different teaching methods implemented?

- At what levels are the prospective teachers in the experimental group in terms of attitudes towards PBL? 
- At what levels are the prospective teachers in the experimental group in terms of self-efficacy perceptions of PBL?

- Are prospective teachers' attitudes towards and self-efficacy perceptions of PBL the significant predictors of their self-regulated learning skills?

\section{Method}

Posttest only control group design was used in the study. In this design testing is not a possible threat, because none of the subjects in the study are measured twice (Fraenkel \& Wallen, 2006).

\subsection{Study group}

The sample for the study consisted of 49 prospective teachers from the Department of Secondary Science and Mathematics Education, Hacettepe University, Ankara, who participated in the spring term of the 2011-2012 academic year. They were first year students at Hacettepe University.

\subsection{Data collection tools}

\subsubsection{The self-regulated learning scale}

The scale, developed by Turan and Demirel (2010), is a 41-item, 5-point Likert-type scale. Following the factor analysis conducted, the items in the scale were put under 4 factors whose eigenvalues were bigger than 1.5. The first of the important items accounted for $18.36 \%$ of the total variance while the second accounted for $16.94 \%$, the third acounted for $11.95 \%$, and the fourth accounted for $7.87 \%$; and the $47.10 \%$ in total. The Cronbach's alpha reliability coefficients for the factors were $0.88,0.91,0.83$, and 0.76 respectively, and 0.91 for all the items.

\subsubsection{The attitude scale for problem-based learning}

The scale developed by Turan and Demirel (2009) constituted 20 propositions with equal number of positive and negative propositions. It is a 5-point Likert-type scale. The Cronbach's alpha reliability coefficient for the scale was 0.95 . Factor analysis was conducted so as to obtain evidence of construct validity. In consequence, it was found that the positive and negative items of the scale clustered on two different dimensions in the factor analysis, and that the scale accounted for a considerable part of total variance (61.32\% in the first analysis, and $58.87 \%$ in the second one).

\subsubsection{The scale of self-efficacy perception of problem-based learning}

The scale developed by Onan, Turan and Başusta (2010) contained 18 items. 9 of them were under the heading of group interaction, 5 under problem-solving, and 4 under responsibility in the trio factor structure. The Kaiser-Meyer-Olkin (KMO) coefficient was found to be 0.935 , whereas the variance accounted by the factors was $53.42 \%$, and the Cronbach's alpha reliability coefficient for the whole scale was 0.905 .

\subsection{The procedures of application}

The study was conducted in the Spring semester of 2011-2012 academic year. The topic of acid base related to daily life was chosen for the study purposes. The prospective teachers were randomly assigned to experimental group (22) and control group (27) according to their semester scores in General Chemistry I and Basic Chemistry I during the autumn semester in the 2011-2012 academic year. They were informed of the purpose of the study. Then the prospective teachers in the experimental group were told about problem-based learning. What application procedures problem-based learning contained was explained to them. The prospective teachers in the experimental group were randomly assigned to 5 groups. The teaching of the acid base topic was performed through PBL in the experimental group while it was done through the traditional method in the control group. The PBL was fulfilled in 5 sessions. At the final stage of the study, the experimental group was given The Attitude Scale Towards Problem-Based Learning as well as The Scale of Self-Efficacy Perception of Problem-Based Learning while both the experimental group and control group were given The SelfRegulated Learning Scale. 


\subsection{Data Analysis}

Descriptive statistics (mean and standard deviation), multiple linear regression and independent samples t-test were employed in the data analysis.

\section{Results}

The results for the independent samples t-test in relation to the first research problem are shown in Table 1.

Table 1. The results for the independent samples t-test in relation to the scores of experimental and control group prospective teachers' self-regulated learning skills

\begin{tabular}{|c|c|c|c|c|c|c|}
\hline Groups & $\mathrm{N}$ & $\overline{\mathrm{x}}$ & $\mathrm{S}$ & $\mathrm{sd}$ & $\mathrm{t}$ & $\mathrm{p}$ \\
\hline Experimental & 22 & 158.727 & 23.879 & & -0.033 & 0.974 \\
\hline Control & 27 & 158.925 & 17.836 & & & \\
\hline
\end{tabular}

An examination of Table 1 shows that there is no significant difference between the self-regulated learning skill scores of prospective teachers in both the experimental and control group ( $t=-0.033, p>0.05)$.

In relation to the second research problem, the study performed by Turan and Demirel (2011) was taken into consideration in determining the levels of attitudes towards the PBL of prospective teachers in the experimental group. The mean score for prospective teachers' attitudes towards the PBL was found as $\bar{x}=60.50$, and the standard deviation was calculated as $S=11.47$. Because those with attitudes scores of \pm 1 standard deviation (those having scores between 49 and 71 ) were regarded as middle, those with scores above 1 standard deviation as positive and those with scores below 1 standard deviation were regarded as negative, it may be said that the mean score obtained was $(\bar{x}=60.50)$ at the middle level.

In relation to the third research problem, the mean score of self-efficacy perceptions of PBL of prospective teachers in the experimental group was calculated as $\bar{x}=72.09$ and the standard deviation as $S=6.85$. Because those with self-efficacy scores of \pm 1 standard deviation (those having scores between 66 and 77) were regarded as middle, those with scores above 1 standard deviation as positive and those with scores below 1 standard deviation were regarded as negative, it may be said that the mean score obtained was $(\bar{x}=72.09)$ at the middle level.

The multiple regression analysis results in relation to the fourth research problem are shown in Table 2.

Table 2. The multiple respression analysis results in relation to predicting the self-regulated learning skills of prospective teachers in both the experimental and control group

\begin{tabular}{|c|c|c|c|c|c|c|c|}
\hline \multirow{2}{*}{ Model } & \multicolumn{2}{|c|}{ Unstandardized coefficients } & \multirow{2}{*}{$\beta$} & $\mathrm{t}$ & $\mathrm{p}$ & \multirow{2}{*}{ Zero-order } & \multirow{2}{*}{ partial } \\
\cline { 2 - 6 } & $\mathrm{B}$ & Std.error & & & & & \\
\hline Constant & -24.546 & 43.757 & & -.561 & .581 & & \\
\hline Self-efficacy perception & 2.339 & .593 & .658 & 3.943 & .001 & .689 & .671 \\
\hline Attitude & 0.310 & .354 & .146 & .177 & .393 & .285 & .196 \\
\hline $\mathrm{R}=0.703, \mathrm{R}^{2}=0.4905, \mathrm{~F}(2,21)$ & $=9.302, \mathrm{p}=.002$ \\
\hline
\end{tabular}

On examining the zero-order and partial correlations between predictor variables (self-efficacy perception and attitude) and the dependent variable (self-regulated learning skill) in Table 2, it becomes evident that a positive correlation at the intermediate level is available between self-efficacy perception and self-regulated learning skills $(r=0.68)$; but when the other variable is controlled, the correlation between the two variables is $r=0.67$. Besides, the positive and low level zeroorder correlation between attitude and self-regulated learning skill was calculated as $r=0.28$, and when the other variable is controlled, it is positive and low level $(r=0.19)$. Self-efficacy perception and attitude variables together have high and significant correlations with self-regulated learning skills $\left(R=0.703, R^{2}=0.4905, F(2,21)=9.302, p<.05\right)$. Both variables together acoount for $49 \%$ of the total variance in prospective teachers' self-regulated learning skills. According to the standardised regression coefficient ( $\beta$ ), however, the relative order of importance on self-regulated learning skills is: selfefficacy perception and attitude. 


\section{Conclusion and Discussion}

According to the results of the independent samples t-test which was done in relation to the first research problem, there is no significant difference between the scores of the self-regulated learning skill scores of prospective teachers in both the experimental and control group. Accordingly, it may be said that problem-based learning and the traditional teaching method do not have significant effects on prospective teachers' self-regulated learning skills. Besides, no research studies were encountered in literature examining the effects of PBL on the development of self-regulated learning, especially in science education.

In consequence of the descriptive statistics performed in relation to the second and third research problems, it may be stated that prospective teachers are at the middle level in terms of attitudes towards PBL and of their self-efficacy perceptions of PBL. Study findings of Rajab (2007) revealed that students enrolled in a PBL class exhibited greater gains in biology self-efficacy and were likely to report more favorable attitudes toward biology compared to students enrolled in a traditional class. Students had favorable attitudes toward PBL regardless of their pre-treatment self-efficacy and achievement levels.

According to the results of multiple regression analysis performed in relation to the fourth research problem, selfefficacy perception along with attitude variable was found to have high significant correlation with self-regulated learning skills. It may be said that both variables together acoount for $49 \%$ of the total variance in prospective teachers' selfregulated learning skills. A review of literature showed that the number of research studies regarding the correlation between self-efficacy perception and self-regulatory skills at university level was not high (İsrael, 2007; Ng, 2002); but that studies concerning attitudes towards PBL were mostly performed in the field of medicine (Birgegard \& Lindquist, 1998; Kaufman \& Mann, 1996; Vernon, 1995).

Based on an overall evaluation of the results obtained in the study, it may be said that the fact that prospective teachers' attitudes towards and their self-efficacy perceptions of PBL was at the middle level was a satisfactory result. Because knowing an individual's attitudes towards an object or a stimulus helps us predict what that person's behaviour will be against the relevant stimulus (Üstüner, 2006), this result displays the probability that the prospective teachers prefer PBL in the future in their classes. Yet, because attitude and self-efficacy are gained through experience, opportunities should be given to prospective teachers to encounter such approaches as the PBL. Especially, "PBL's collaborative process provides explicit feedback to students about their performance, serving as a source of efficacy information that enhances self-efficacy development" (Dunlop, 2005, p. 78).

The fact that prospective teachers had faced with PBL- an approach of learning different from the traditional appraoch- for the first time may be the cause for not having a significant effect on their self-regulated learning skills. Another reason could be that the application time period of the PBL might not have been sufficient for the development of their self-regulated learning skills. Turan and Demirel (2010), on the other hand, pointed out that gaining self-regulated learning skills takes time even if it is possible to gain it with experience.

Being able to plan a learning activity and to monitor and evaluate it does not automatically imply that one can steer and direct one's learning process without the help and support of the teacher or the textbook (Winne, 1995). Teachers and learning environments play important roles in students' gain of self-regulated learning skills (Eshel \& Kohavi, 2003). Therefore, the importance of self-regulated learning should be explained to prospective teachers, and they should be provided with models and guides so that they can become self-regulated learners. Methods capable of developing their self-regulated learning skills should be used in classes. Prospective teachers should also be provided with opportunities to develop those skills. As mentioned by Paris and Paris (2001), "self-regulated learning is also more likely when teachers create classroom environments in which students have opportunities to seek challenges, to reflect on their progress, and to take responsibility and pride in their accomplishment" (p. 99).

\section{References}

Bandura, A. (1982). Self-efficacy mechanism in human agency. American Psychologist, 37(2), 122-147.

Bandura, A. (1986). Social foundations of thought and action: A social cognitive theory. Englewood Cliffs, N.J.: Prentice-Hall.

Birgegard, G., \& Lindquist, U. (1998). Change in student attitudes to medical school after the introduction of problem-based learning in spite of low ratings. Medical Education, 32, 46-49.

Boekaerts, M. E. (1999). Self-regulated learning: Where we are today. International Journal of Educational Research, 31(6), $445-447$.

Dunlop, J. C. (2005). Problem-based learning and self-efficacy: How a capstone course prepares students for a profession. Educational Technology Research and Development, 53(1), 65-83.

Ertmer, P. A., Newby, T. J., \& MacDougall, M. (1996). Students' approaches to learning from case-based instruction: The role of 
reflective self-regulation. American Educational Research Journal, 33(3), 719-752.

Eshel, Y., \& Kohavi, R. (2003). Perceived classroom control, self-regulated learning strategies, and academic achievement. Educational Psychology, 23(3), 249-260.

Fraenkel, J. R., \& Wallen, N. E. (2006). How to design and evaluate research in education (6th ed.). New York: McGraw-Hill International Edition.

Gömleksiz, M. N. (2003). İngilizce duyuşsal alana ilişkin bir tutum ölçeğinin geçerlik ve güvenirliği. Fırat Üniversitesi Sosyal Bilimler Dergisi, 13(1), 215-226.

İsrael, E. (2007). Özdüzenleme eğitimi, fen başarısı ve özyeterlilik. Doktora tezi, Dokuz Eylül Üniversitesi, İzmir.

Kağıtçıbaşı, Ç. (1996). Insan ve insanlar (9. Baskı). İstanbul: Evrim Basım.

Kaufman, D. M., \& Mann, K. V. (1996). Students' perceptions about their courses in problem-based learning and conventional curricula. Academic Medicine, 71(1), 52-54.

Lee, T-H., Shen, P-D., \& Tsai, C-W. (2010). Enhance low-achieving students' learning involvement in Taiwan's higher education: An approach via e-learning with problem-based learning and self-regulated learning. Teaching in Higher Education, 15(5), 553-565.

$\mathrm{Ng}, \mathrm{C}$. (2002). Relations between motivational goals, beliefs, strategy use and learning outcomes among university students in a distance learning mode: A longitudinal study. Paper presented at the Annual Conference of Australian Association for Research in Education, Brisbane, Retrieved May 15, 2013, from http://publications.aare.edu.au/02pap/ng02462.htm.

Onan, A., Turan, S., \& Başusta, N. B. (2010). Probleme dayalı öğrenmeye yönelik özyeterlilik algısı ölçeğinin geçerlilik ve güvenilirlik çalışması. Hacettepe Tıp Dergisi, 41, 231-239.

Pajares, F. (1996). Self-efficacy beliefs in achievement settings. Review of Educational Research, 66, 543-578.

Paris, S. G., \& Paris, A. H. (2001). Classroom applications of research on self-regulated learning. Educational Psychologist, 36, 89-91.

Perry, N. E., \& Drummond, L. (2002). Helping young students become self-regulated researchers and writers. The Reading Teacher, 56(3), 298-310.

Pintrich, P. R. (1989). The dynamic interplay of student motivation and cognition in the college classroom. In C. Ames \& M. L. Maehr (Eds.), Advances in motivation and achievement: Motivation enhancing environments (pp. 117-160). Greenwich, CT: JAI Press.

Pintrich, P. R., \& De Groot, E. V. (1990). Motivational and self-regulated learning components of classroom academic performance. Journal of Educational Psychology, 82(1), 33-40.

Pintrich, P. R., \& Garcia, T. (1991). Student goal orientation and self-regulation in the college classroom. In M. L. Maehr, \& P. R. Pintrich (Eds.), Advances in motivation and achievement: Goals and self-regulatory processes (pp. 371-402). Greenwich, CT: JAI Press.

Pintrich, P. R. (1999). The role of motivation in promoting and sustaining self-regulated learning. International Journal of Educational Research, 31, 459-470.

Rajab A. M. (2007). The effects of problem-based learning on the self efficacy and attitudes of beginning biology majors. Doctoral dissertation. University of California, Los Angeles.

Rizemberg, R., \& Zimmerman, B. J. (1992). Self-regulated learning in gifted students. Roeper Review, 15(1), 98-101.

Schunk, D. H., \& Zimmerman, B. J. (Eds.). (1998). Self-regulated learning: From teaching to self-reflective practice. New York: Guilford Press.

Senemoğlu, N. (2011). Gelişim öğrenme ve öğretim: Kuramdan uygulamaya (20.Baskı). Ankara: Gazi Kitabevi.

Sungur, S, \& Tekkaya, C (2006). Effects of problem-based learning and traditional instruction on self-regulated learning. The Journal of Educational Research, 99, 307-317.

Taşkın, (2008). Fen ve teknoloji öğretiminde yeni yaklaşımlar. Ankara: Pegem Akademi.

Tosun, C., \& Şenocak, E. (2013). The effects of problem-based learning on metacognitive awareness and attitudes toward chemistry of prospective teachers with different academic backgrounds. Australian Journal of Teacher Education, 38(3), 61-73.

Turan, S., \& Demirel, Ö (2009). Probleme dayalı öğrenmeye ilişkin tutum ölçeği geçerlik ve güvenirlik çalışması. Eğitim ve Bilim, 34(152), 15-29.

Turan, S., \& Demirel, Ö (2010). Öz-düzenleyici öğrenme becerilerinin akademik başarı ile ilişkisi: Hacettepe Üniversitesi Tıp Fakültesi Örneği. Hacettepe Üniversitesi Eğitim Fakültesi Dergisi, 38, 279-291.

Turan, S., \& Demirel, Ö (2011). Hacettepe Üniversitesi Tıp Fakültesi öğrencilerinin probleme dayalı öğrenmeye yönelik tutumları ve görüşleri. Eğitim ve Bilim, 36, 162.

Üredi, I., \& Üredi, L. (2007). Öğrencilerin öz-düzenleme becerilerini geliştiren öğrenme ortamının oluşturulması. EDU, 7, 2.

Üstüner, M. (2006). Öğretmenlik mesleğine yönelik tutum ölçeğinin geçerlik ve güvenirlik çalışması. Kuram ve Uygulamada Eğitim Yönetimi, 12(45), 109-127.

Vernon, D. T. (1995). Attitudes and opinions of faculty tutors about problem-based learning. Academic Medicine, 70(3) 216-223.

Winne, P. H. (1995). Inherent details in self-regulated learning. Educational Psychologist, 30, 173-187. 